\title{
Article \\ Physiological and Regenerative Plant Traits Explain Vegetation Regeneration under Different Severity Levels in Mediterranean Fire-Prone Ecosystems
}

\author{
Sara Huerta ${ }^{1}\left(\mathbb{D}\right.$, Víctor Fernández-García ${ }^{1}\left(\mathbb{D}\right.$, Elena Marcos ${ }^{1} \mathbb{D}$, Susana Suárez-Seoane ${ }^{2} \mathbb{D}$ and Leonor Calvo ${ }^{1, *(\mathbb{D})}$ \\ 1 Area of Ecology, Department of Biodiversity and Environmental Management, Faculty of Biological and \\ Environmental Sciences, Universidad de León, 24071 León, Spain; shueg@unileon.es (S.H.); \\ vferg@unileon.es (V.F.-G.); elena.marcos@unileon.es (E.M.) \\ 2 Department of Organisms and Systems Biology (Ecology Unit) and Research Unit of Biodiversity (UMIB-UO-CSIC-PA), \\ Universidad de Oviedo, 33071 Oviedo, Mieres, Spain; s.seoane@uniovi.es \\ * Correspondence: leonor.calvo@unileon.es
}

Citation: Huerta, S.;

Fernández-García, V.; Marcos, E.;

Suárez-Seoane, S.; Calvo, L.

Physiological and Regenerative Plant Traits Explain Vegetation

Regeneration under Different Severity

Levels in Mediterranean Fire-Prone

Ecosystems. Forests 2021, 12, 149.

https://doi.org/10.3390/f12020149

Received: 29 December 2020

Accepted: 26 January 2021

Published: 27 January 2021

Publisher's Note: MDPI stays neutral with regard to jurisdictional claims in published maps and institutional affiliations.

Copyright: (c) 2021 by the authors. Licensee MDPI, Basel, Switzerland. This article is an open access article distributed under the terms and conditions of the Creative Commons Attribution (CC BY) license (https:/ / creativecommons.org/licenses/by/ $4.0 /)$.

\begin{abstract}
In Mediterranean fire-prone ecosystems, plant functional traits and burn severity have decisive roles in post-fire vegetation recovery. These traits may reflect plant fitness to fire regimes in the Mediterranean Basin. The aim of this study was to evaluate the effect of burn severity on post-fire vegetation regeneration through plant functional (physiological and regenerative) traits in two Mediterranean ecosystems: one more humid and colder (Cabrera in León province, NW Spain), and another characterized by a longer summer drought (Gátova in Valencia province, SE Spain). A total of 384 and 80 field plots $(2 \mathrm{~m} \times 2 \mathrm{~m})$ were fixed in Cabrera and Gátova, respectively. In each burned plot, we quantified burn severity by means of the composite burn index (CBI), differentiating three severity levels (low, moderate, and high), and evaluated post-fire vegetation regeneration one and two years after wildfires. We measured the percentage cover of each species and classified them according to physiological (specific leaf area and $\mathrm{N}_{2}$-fixing capacity) and regenerative traits (reproductive strategy, bud bank location, and heat-stimulated germination). The main results showed that in Cabrera, burn severity had significant effects on vegetation cover independently of plant functional traits. In Gátova, burn severity effects differed among functional traits. In this site, the cover of plants with low specific leaf area and without heat-stimulation and $\mathrm{N}_{2}$-fixing capacity was negatively related to burn severity. On the contrary, the cover of $\mathrm{N}_{2}$-fixers and species with resprouting ability and heat-stimulated germination rose with increasing burn severity. In general, vegetation cover showed a more pronounced increased over time in the more humid area, mainly under the effect of high severity. The results of this research highlighted the importance of the use of plant functional traits as a driver to understand the response of different ecosystems to current fire regimes, which could be relevant for pre- and post-fire management.
\end{abstract}

Keywords: burn severity; Mediterranean Basin; physiological traits; regenerative traits; vegetation regeneration; wildfire

\section{Introduction}

Fire is an important disturbance in forest ecosystem, particularly in those located in Mediterranean regions [1], where it is a relevant ecological element that shapes the landscape [2]. In recent decades, climate change and increasing fuel accumulation caused by land use abandonment (mainly driven by a reduction in traditional agriculture, livestock grazing, and rural population density) have contributed to the alteration of the fire regime in the Mediterranean Basin [3]. This has led to an increase in the number of fires [4], burned area [2], and burn severity [5-7]. These changes in the fire regime have influenced plant community structure [8], especially the presence of species with reproductive traits that allow them to persist after fire $[9,10]$. In this sense, the regeneration of plant communities 
is strongly affected by burn severity [11-14]. In addition, climatic conditions characterized by a decrease in the water availability for plants constrains their response to wildfire, mainly because of its implication in the productivity of the plant community after fire [15]. Thus, the effect of fire on ecosystems is influenced by the pre-fire vegetation state and the adaptive traits of plants [16-21].

According to Violle et al. [22], plant functional traits are classified as morpho-physiophenological traits that influence plant fitness by their effects on growth, reproduction, and survival. Functional traits are particularly relevant in fire-prone ecosystems, where fire regimes may shape the evolution of these plant characteristics [23], because they determine the ability of plants to reproduce and survive [24]. Therefore, many authors have studied the relationships between fire and plant functional traits in order to evaluate vegetation behavior and response to fire regimes in Mediterranean ecosystems [15,19,25-28]. In this context, burn severity plays an important role in shaping the types of vegetation after fire $[21,28]$. From a physiological point of view, specific leaf area (SLA, leaf area per unit dry mass) is one of the most studied functional traits [28-32]. This trait may provide information about vegetation productivity and is considered to be an indicator of resource use strategies $[29,33]$. Low SLA is often related to species with lower growth rates, net photosynthetic capacity, and leaf nitrogen $(\mathrm{N})$ concentration [34], but with a longer leaf life-span [35]. On the contrary, species with high SLA are associated with faster growing and shorter leaf life-spans [36], which could be a good strategy in areas frequently affected by severe fires [28]. Post-fire vegetation growth and recovery are also related to soil nutrient concentrations [37,38], $\mathrm{N}$ being one of the most limiting nutrients in terrestrial ecosystems [39,40]. Leguminous and actinorhizal plant species can fix $\mathrm{N}_{2}$ from the atmosphere through a symbiotic association with $\mathrm{N}_{2}$-fixing rhizobia and Frankia bacteria, a process that occurs in the root nodules [41,42]. Therefore, the presence of $\mathrm{N}_{2}$-fixing species after fire may contribute to recovering soil $\mathrm{N}$ losses by combustion [43,44], which is highly relevant in areas frequently affected by wildfires [45].

Plant regenerative traits modulate post-fire vegetation persistence $[9,16,18,27,46-48]$. In this sense, plants can be classified as obligate seeders or resprouters based on their ability to regenerate by germination or resprouting, respectively, and facultatives in cases where they present both mechanisms [49]. In this context, the type of species present before disturbance is closely related to post-fire vegetation development [19]. Obligate seeder species in Mediterranean ecosystems usually present faster growth rates and shorter life cycles than resprouters [50-52], so they easily recover during the first years after fire [53]. This is mainly explained by the fact that some of these species have fire-resistant seeds [54], which may be stimulated by the temperatures reached during the fire [54-59]. Therefore, heat-stimulated germination may help vegetation to persist in fire-prone ecosystems [60]. However, temperatures reached under high severity fire conditions may be lethal for seeds, preventing seedling recruitment [14].

Resprouter species can regenerate vegetatively because they have aboveground and belowground latent buds that form bud banks [61], which are protected by bark or leaf bases and by soil, respectively [62]. These species depend on carbohydrates and nutrient reserves, which are mobilized after a disturbance to resprout [63]. Therefore, the resprouting capacity usually accelerates post-fire regeneration, even after frequent fires [18,52,64]. Despite this, high severity situations are often related to poor regeneration of species with aboveground buds, mainly because of consumption of the aerial biomass [65]. Therefore, resprouting from belowground buds, which are protected by soil, is an advantageous strategy to survive after severe disturbances [62].

The relationship between burn severity and plant functional traits was previously studied in Mediterranean ecosystems [13,21,28,66,67]. However, we found no evidence of studies focused on explaining vegetation response to burn severity over the short term as a function of plant physiological and regenerative traits, comparing areas with different vegetation composition and structure. 
Therefore, we aimed to assess the effect of burn severity on vegetation regeneration according to some plant functional traits in two different Mediterranean ecosystems. Specifically, we wanted to (1) evaluate vegetation regeneration as a function of burn severity through physiological traits (specific leaf area (SLA) and $\mathrm{N}_{2}$-fixing capacity), and regenerative traits (reproductive strategy, bud bank location, and heat-stimulated germination) over the short term after wildfire; (2) analyze changes in vegetation regeneration over time; and (3) compare post-fire vegetation regeneration in areas with different vegetation composition under different climatic conditions.

For the case of plant physiological traits, we expected better regeneration of high SLA species, since they are associated with faster growth rates than those with low SLA [34,36]. We also assumed good regeneration of $\mathrm{N}_{2}$-fixing species due to their implications in the recovery of the soil $\mathrm{N}$ after fire $[44,68]$. With regards to regenerative traits, we hypothesized that high burn severity could negatively affect the regeneration of obligate seeders because of the effect on seed mortality [14]. Furthermore, it was expected that the presence of protected storage organs allows species with resprouting ability to persist even at high severities [65,67]. Moreover, climatic conditions could influence vegetation regeneration in Mediterranean areas with lower mean precipitation and hotter drier summers [14,28], mainly because of water availability and post-fire drought effects on vegetation recovery [69-71].

\section{Materials and Methods}

\subsection{Study Areas}

We selected two study sites affected by wildfires in summer 2017: the Cabrera mountain range in León province (NW Iberian Peninsula) and Gátova, located in the Calderona mountain range, Valencia province (SE Iberian Peninsula) (Figure 1).

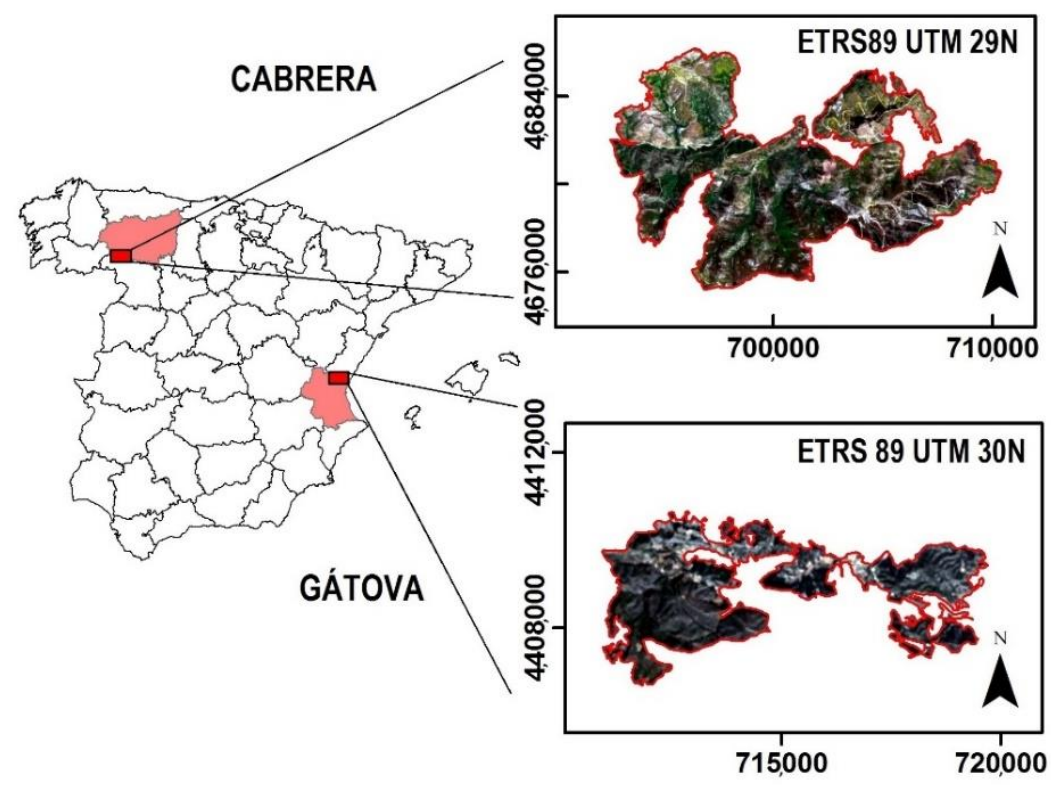

Figure 1. Location of the study areas in the Iberian Peninsula (left). Panels on the right show the perimeters of the Cabrera (top) and Gátova (bottom) wildfires.

In the Cabrera study area, wildfire affected 9939 ha, burning communities dominated by Genista hystrix Lange, Erica australis L., Cytisus scoparius (L.) Link, and Quercus pyrenaica Willd. This area presents a Mediterranean climate, with dry temperate summers [72]. The mean annual temperature is $9{ }^{\circ} \mathrm{C}$, while average annual precipitation is 700-800 mm [73]. This site has mountainous orography, and altitudes range from 836 to 1938 m.a.s.l. Soils are acidic ( $\mathrm{pH}$ around 5), with slates, sandstones, and quartzites from the Ordovician period as the predominant type of rocks [74]. 
The Gátova wildfire burned 1414 ha of Pinus halepensis Mill. forests with an understory vegetation dominated mainly by Rosmarinus officinalis L., Ulex parviflorus Pourr., Quercus coccifera L., and Erica multiflora L. This area has a Mediterranean climate, with hot, dry summers [72]. Mean annual temperature and precipitation are $15^{\circ} \mathrm{C}$ and $400-600 \mathrm{~mm}$, respectively [73]. It is a mountainous region, with heterogeneous orography. Elevation ranges from 290 to 815 m.a.s.l. It is characterized by alkaline soils ( $\mathrm{pH}$ around 8), and the predominant lithology includes dolomites, limestones, sandstones, clays, and marls from the Triassic period [74].

\subsection{Field Sampling}

We randomly fixed a total of 384 field plots in Cabrera and 80 plots in Gátova $(2 \mathrm{~m} \times 2 \mathrm{~m})$, covering fire perimeters and unburned areas. In each burned plot, we evaluated burn severity by the application of the composite burn index procedure (CBI), adapted by Fernández-García et al. [75]. According to them, we visually rated from a score of 0 (unburned) to 3 (maximal burn severity) several burn severity indicators (e.g., litter consumed, char depth and soil color, foliage consumed, char height, tree mortality, and canopy color) in 5 vertical strata of soil and vegetation. The final score of the plot was obtained with the average of all the evaluated strata. In the Cabrera study area, we established 88 unburned plots, 80 at low severity, 100 at moderate severity, and 116 at high severity. In Gátova, we fixed 20 unburned plots, 20 at low severity, 20 at moderate severity, and 20 at high severity. Every burned and unburned plot $(2 \mathrm{~m} \times 2 \mathrm{~m})$ was divided into four $1 \mathrm{~m} \times 1 \mathrm{~m}$ sampling units. The percentage cover of each woody species was visually estimated in every sampling unit. Then, we calculated the average cover of each woody species for each $2 \mathrm{~m} \times 2 \mathrm{~m}$ plot. With the aim of analyzing vegetation changes over time, burned plots were monitored one and two years after the wildfires. Specifically, field samplings were carried out during the months of June and July 2018 and 2019. We used a high precision GPS to georeference the plot centers.

\subsection{Plant Functional Traits}

Woody species were classified according to the following functional traits (Tables S1 and S2): (1) Physiological traits: specific leaf area (SLA) (low or high) and $\mathrm{N}_{2}$-fixing capacity (yes or no); and (2) regenerative traits: reproductive strategy (resprouter, obligate seeder, facultative), bud bank location (aboveground or belowground), and heat-stimulated germination (yes or no). Vegetation trait classification was based on the BROT 2.0 database [76], bibliographic review $[18,48,77-81]$, personal communications, and field observations.

\subsection{Data Analysis}

To analyze the effects of burn severity and time after fire on vegetation regeneration, we fitted generalized linear mixed models (GLMMs) with a quasi-Poisson error distribution ( $\log$ link function) and a penalized quasi-likelihood approximation (glmmPQL function) to account for overdispersion. Data for all $2 \mathrm{~m} \times 2 \mathrm{~m}$ plots from one (2018) and two (2019) years after the wildfires were included in the analysis $(n=384$ in Cabrera and $n=80$ in Gátova). The predictor variables in the GLMMs were burn severity categories (unburned, low, moderate, and high), calculated with the CBI scoring, the time after fire (one and two years), and their interaction (severity $\times$ time). The response variables in the models were the percentage cover of vegetation differentiated by functional traits. For physiological traits, we analyzed (1) low SLA, (2) high SLA, (3) $\mathrm{N}_{2}$-fixing, and (4) no $\mathrm{N}_{2}$-fixing capacity. For regenerative traits, we analyzed (1) resprouters, (2) obligate seeders, (3) facultatives, (4) aboveground buds, (5) belowground buds, (6) heat-stimulated germination, and (7) no heat-stimulated germination. The identities of the $2 \mathrm{~m} \times 2 \mathrm{~m}$ field plots were included in each of the models as a random factor. We assumed that differences were significant at a $p$ value $<0.05$.

Data analyses were carried out with R software [82] using MASS [83] and nlme [84] packages. 


\section{Results}

\subsection{Species Cover by Physiological Traits}

Species with different SLA showed an opposite pattern between study areas, both in unburned and burned plots (Figure 2). Species with high SLA dominated in Cabrera, while the cover percentage of low SLA species was higher in Gátova. In both areas, we observed a negative effect of fire on the regeneration of species with low and high SLA during the first year, regardless of burn severity levels (Figure 2). In Cabrera, the cover of low and high SLA species increased over time (Table S3). Two years after fire, we found that high SLA species cover significantly increased under high severity situations $(p<0.01)$ compared to low and moderate severities (Figure 2). In Gátova, the cover of both groups also increased after two years (Table S4). However, we observed that fire negatively affected the regeneration of low SLA species $(p<0.001)$.
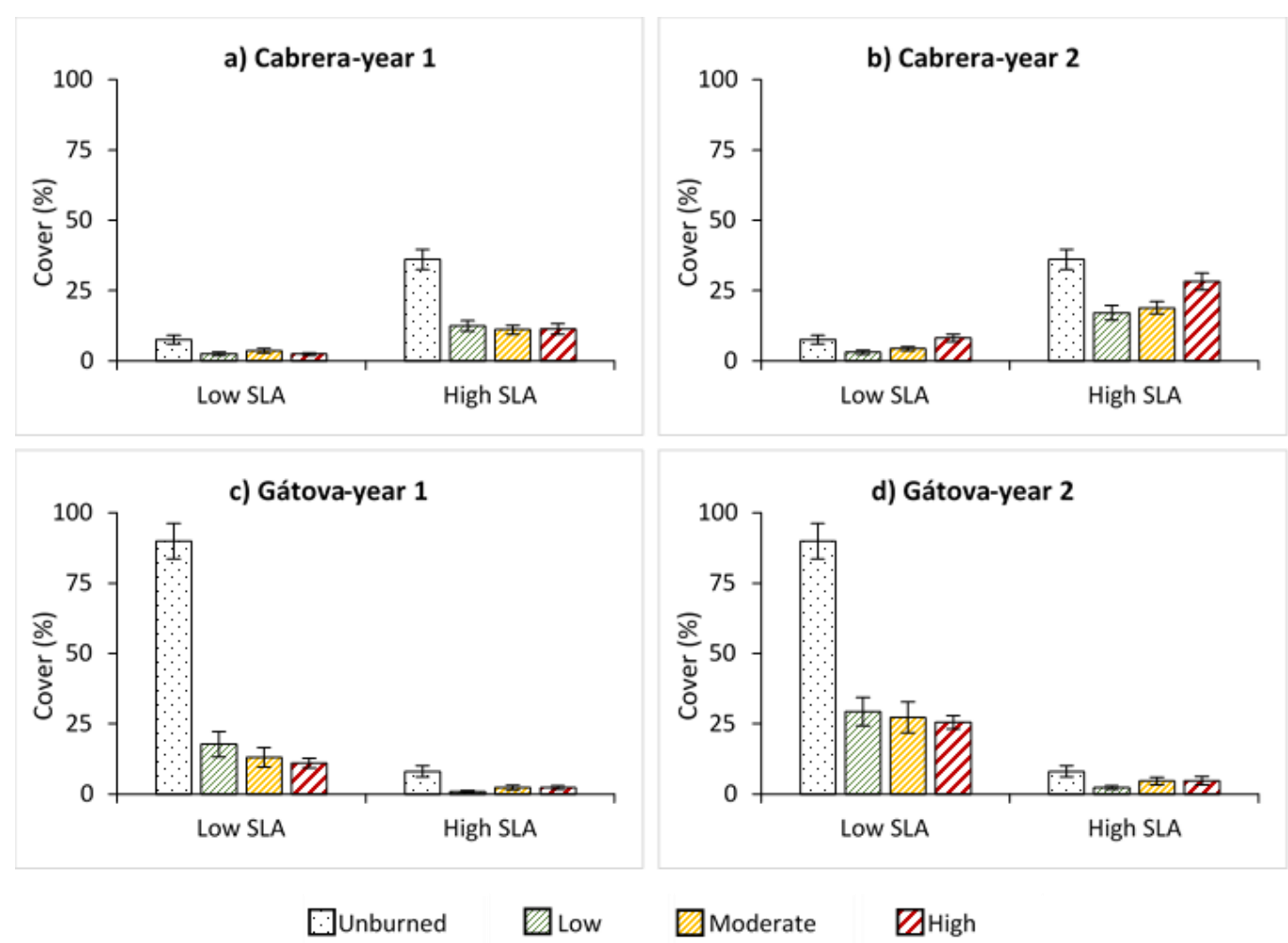

Figure 2. Average cover (\%) of species with low and high specific leaf area (SLA), and standard error for each burn severity level (unburned, low, moderate, and high) measured by the composite burn index (CBI) in: (a) Cabrera, one year post-fire; (b) Cabrera, two years post-fire; (c) Gátova, one year post-fire; and (d) Gátova, two years post-fire. Statistical information is provided in Tables S3 and S4 (Supplementary Material).

In relation to $\mathrm{N}_{2}$-fixing capacity, we observed a similar proportion of $\mathrm{N}_{2}$ - and no $\mathrm{N}_{2}$-fixing species in Cabrera but a clear dominance in the cover of no $\mathrm{N}_{2}$-fixing capacity in Gátova (Figure 3). One year after the Cabrera wildfire, the regeneration of both groups was low under all severity situations. However, time increased the cover of species with both traits (Table S3). Two years after fire, we found a significant increment in the cover of $\mathrm{N}_{2}$-fixing species with burn severity $(p<0.001)$, but without reaching unburned values (Figure 3). In Gátova, the cover of both groups also increased over time (Table S4). We observed that burn severity increased the cover of species with $\mathrm{N}_{2}$-fixing capacity $(p<0.001)$ and reduced that of no $\mathrm{N}_{2}$-fixing species $(p<0.001)$. This pattern was repeated one and two years after fire (Figure 3; Table S4). 

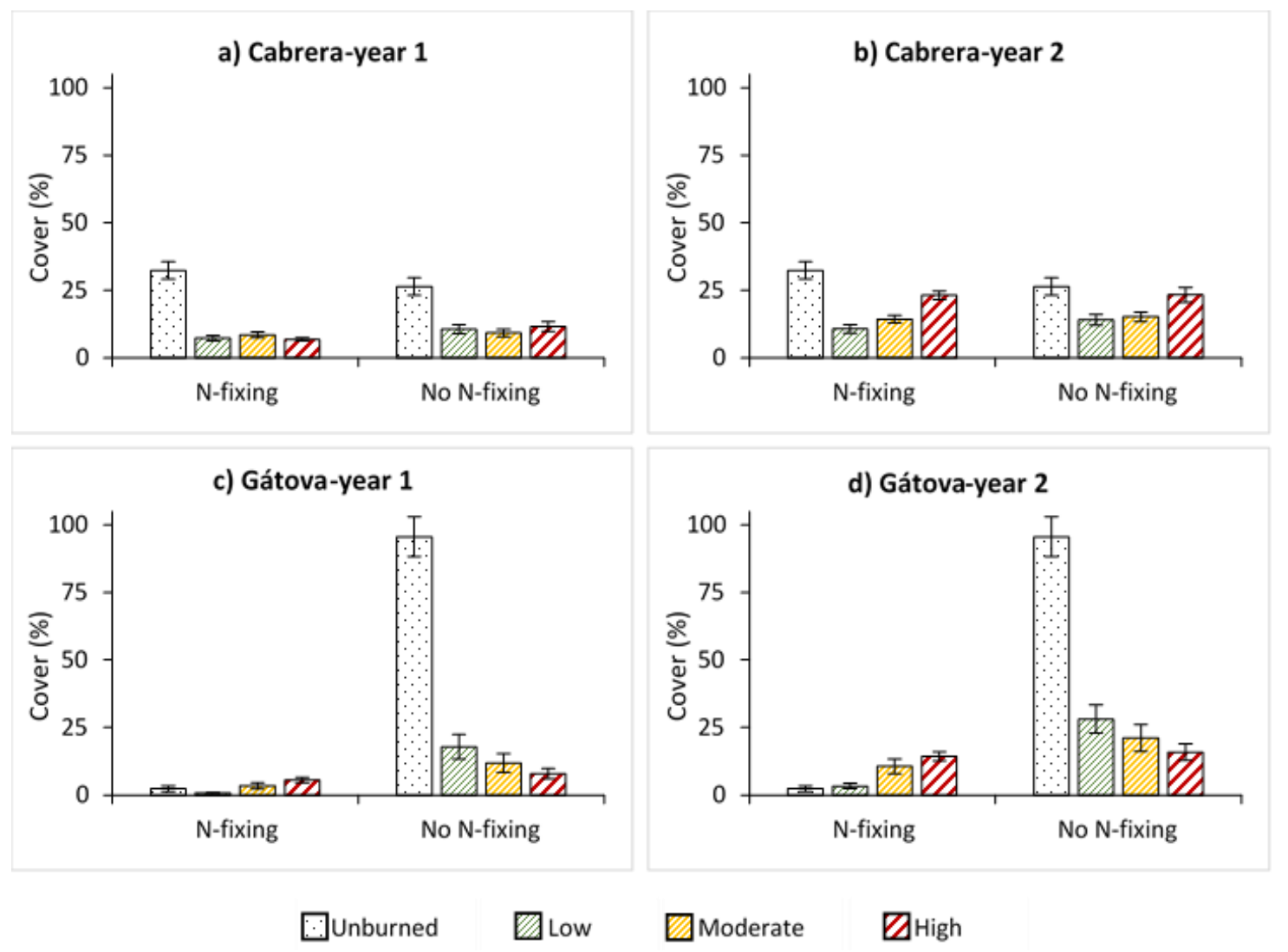

Figure 3. Average cover (\%) of species with $\mathrm{N}_{2}$-fixing and no $\mathrm{N}_{2}$-fixing capacity, and standard error for each burn severity level (unburned, low, moderate, and high) measured by the composite burn index (CBI) in: (a) Cabrera, one year post-fire; (b) Cabrera, two years post-fire; (c) Gátova, one year post-fire; and (d) Gátova, two years post-fire. Statistical information is provided in Tables S3 and S4 (Supplementary Material).

\subsection{Species Cover by Regenerative Traits}

In relation to regenerative traits, there was a clear dominance in the cover of obligate seeders in Gátova, while the highest cover values in Cabrera corresponded to resprouter and facultative species (Figure 4). In general, time increased the cover of all groups (Tables S3 and S4). Two years after fire, we observed an increment in the regeneration of resprouters, obligate seeders, and facultatives with burn severity levels in Cabrera (Table S3). On the contrary, obligate seeders were negatively affected by burn severity in Gátova $(p<0.001)$, both during the first and second year after fire. Nevertheless, moderate and high burn severities significantly increased the cover of facultatives $(p<0.001)$. In this area, resprouter species regeneration was low under all severity situations, both one and two years after fire (Figure 4; Table S4).

In the case of resprouter and facultative species, the cover of those with belowground buds showed a clear dominance in both study areas (Figure 5). We found a significant negative effect of fire during the first year, but time significantly increased the cover values of species with both types of buds (Tables S3 and S4). In Cabrera, percentage cover of above and belowground buds species increased from low to high burn severity two years after the wildfire (Figure 5; Table S3). In Gátova, aboveground buds species showed great regeneration under moderate and high severity situations $(p<0.05)$ (Figure 5; Table S4). 

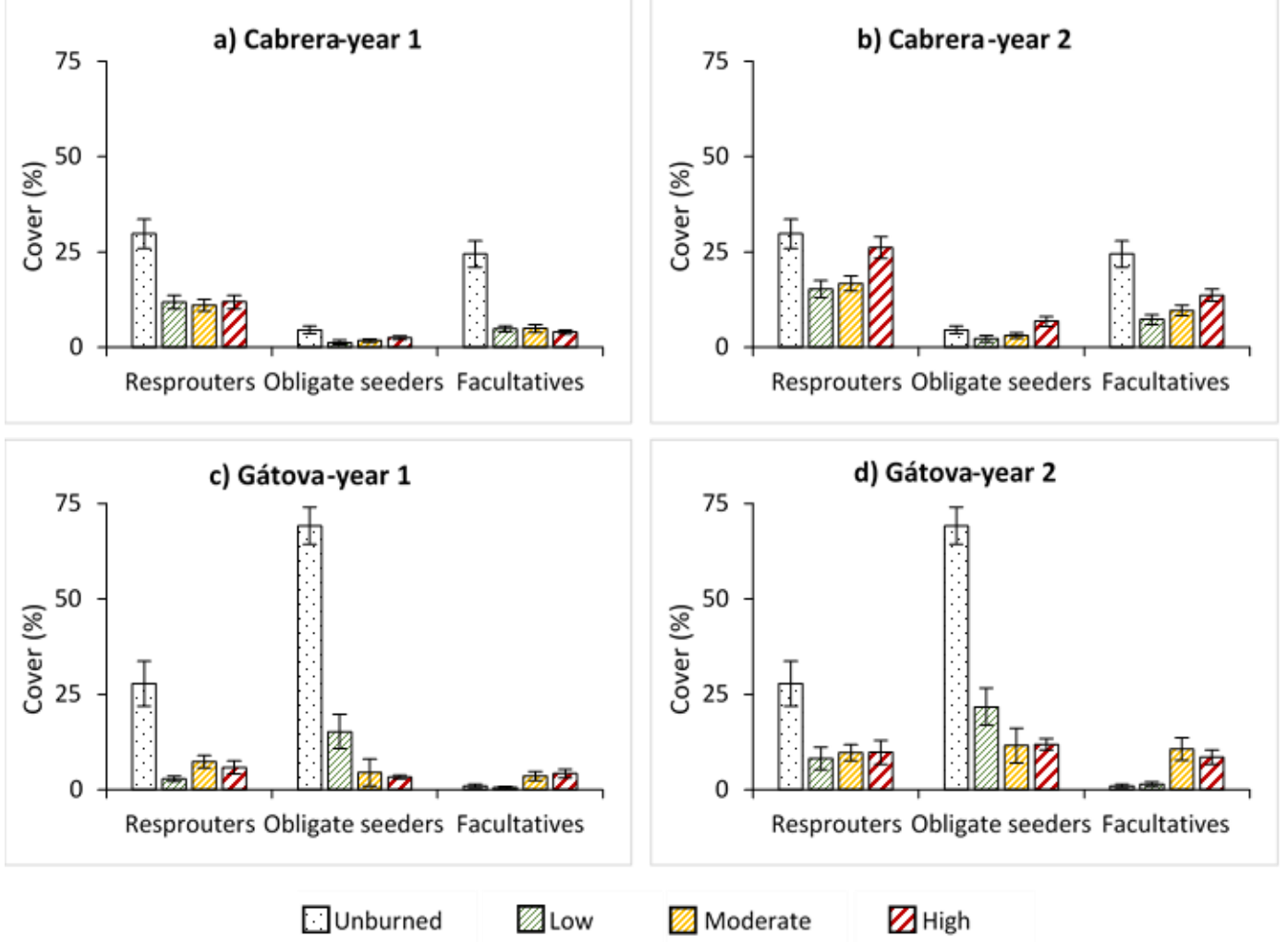

Figure 4. Average cover (\%) of resprouter, obligate seeder, and facultative species, and standard error for each burn severity level (unburned, low, moderate, and high) measured by the composite burn index (CBI) in: (a) Cabrera, one year post-fire; (b) Cabrera, two years post-fire; (c) Gátova, one year post-fire; and (d) Gátova, two years post-fire. Statistical information is provided in Tables S3 and S4 (Supplementary Material).
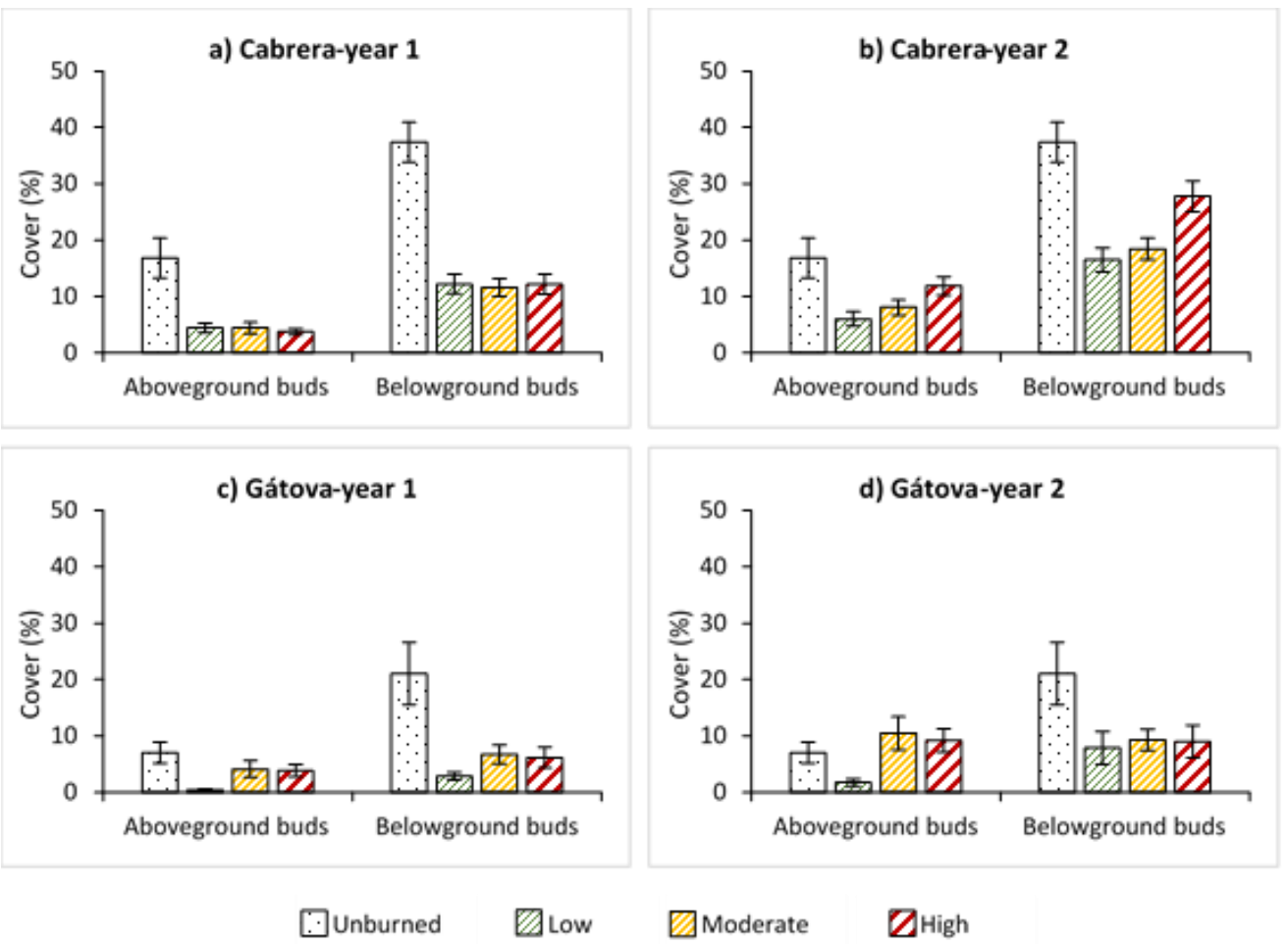

Figure 5. Average cover (\%) of species with aboveground and belowground buds, and standard error for each burn severity level (unburned, low, moderate, and high) measured by the composite burn index (CBI) in: (a) Cabrera, one year post-fire; (b) Cabrera, two years post-fire; (c) Gátova, one year post-fire; and (d) Gátova, two years post-fire. Statistical information is provided in Tables S3 and S4 (Supplementary Material). 
We observed an inverse pattern in the cover of heat and no heat-stimulated species among the study areas, with a dominance of heat-stimulated species in Cabrera and no heat-stimulated species in Gátova (Figure 6). One year after fire, the regeneration of heatstimulated species was low in Cabrera, but their cover significantly increased over time $(p<0.001)$. During the second year, regeneration increased at high severity compared to low and moderate severities (Figure 6; Table S3). In Gátova, we observed an increment in the cover of heat-stimulated species over time and with burn severity, mainly two years after fire (Table S4). However, no heat-stimulated species was negatively affected by burn severity $(p<0.001)$ (Figure 6; Table S4).
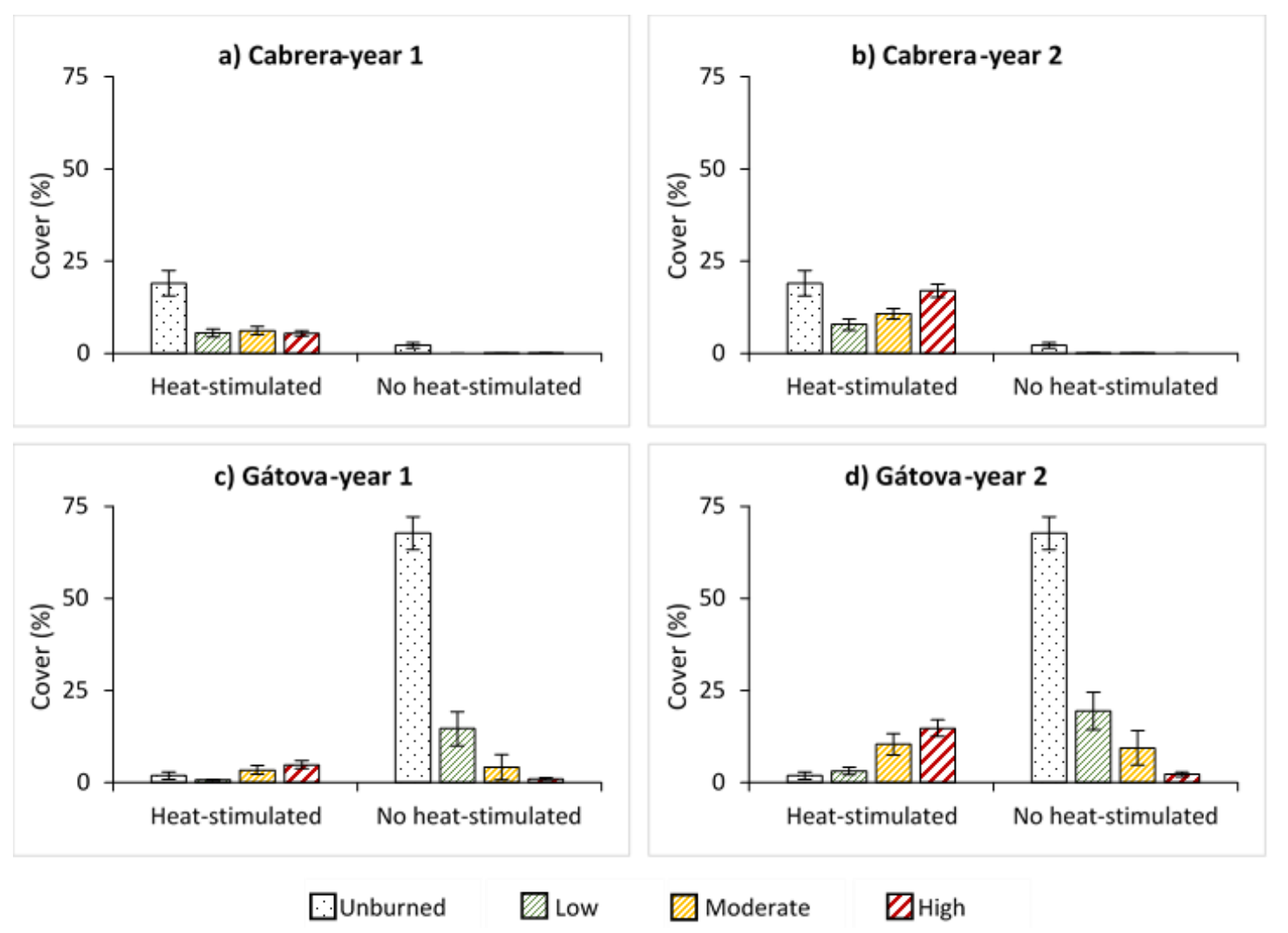

Figure 6. Average cover (\%) of species with heat-stimulated and no heat-stimulated germination, and standard error for each burn severity level (unburned, low, moderate, and high) measured by the composite burn index (CBI) in: (a) Cabrera, one year post-fire; (b) Cabrera, two years post-fire; (c) Gátova, one year post-fire; and (d) Gátova, two years post-fire. Statistical information is provided in Tables S3 and S4 (Supplementary Material).

\section{Discussion}

In the present study, we assessed the effects of burn severity on vegetation regeneration over the short term, based on a series of physiological and regenerative traits, in two fireprone Mediterranean areas of the Iberian Peninsula with different climatic conditions and vegetation composition. According to our results, burn severity affected vegetation regeneration, but plants response was determined by functional traits and showed different behavior in the study areas. Despite these differences, in general, regeneration was low one year after the fires, and vegetation cover increased over time in both study areas. In Cabrera, the area with shorter summer drought, burn severity levels did not significantly influence regeneration during the first year. Nevertheless, vegetation cover generally increased under high severity two years after fire, compared to low and moderate severities. In Gátova, which is characterized by higher average temperatures and lower annual rainfall, different response patterns were observed on vegetation cover depending on the evaluated plant functional traits. In this case, the regeneration of vegetation with predominant 
traits (species with low SLA, without $\mathrm{N}_{2}$-fixing capacity, obligate seeder, and with no heat-stimulated germination) were negatively affected by burn severity.

There was a clear difference in the cover of species with different SLA among study areas. The effects of burn severity on the cover of these species also differed among study sites. In the most humid area, there was a dominance in the cover of species with high SLA, the regeneration of which increased under the effect of high burn severity compared to low and moderate severities two years after fire. Despite this, the cover of high SLA species did not reach unburned levels. The relation between species with high SLA, burn severity, and more humid environments was previously documented in Mediterranean ecosystems [28]. Vegetation with high SLA is usually associated with a greater use of the available resources in the environment, investing less dry matter per leaf and growing fast [36]. In this context, Anacker et al. [29] also related an increment in SLA in areas with higher water availability and showed a relationship between high SLA and resprouter species in a chaparral ecosystem in California. In the Cabrera study site, most of the species with high SLA were shrubs with resprouting ability, mainly Ericaceae species, which presented better regeneration as burn severity increased. In general, shrub vegetation recovers quickly under high severity because it has more open spaces and less competition with tree species, which facilitates its growth and development [12]. On the contrary, species with low SLA dominated in the driest and hottest area, mainly because this trait offers an advantage to avoid drought in areas with low resources [29]. The regeneration of these species was low even two years after fire, which could be attributed to the lesser photosynthetic activity and slower growth rates associated with this type of vegetation [34]. However, burn severity levels hardly influenced the regeneration of these species.

Regarding the $\mathrm{N}_{2}$-fixing capacity, the percentage cover of $\mathrm{N}_{2}$-fixing and no $\mathrm{N}_{2}$-fixing species did not differ in the area with shorter summer drought, while there was a dominance in the cover of species without $\mathrm{N}_{2}$-fixing capacity before fire in the driest area. In spite of this, the regeneration of $\mathrm{N}_{2}$-fixing species significantly increased from low to high severity two years after fire in both study sites. This could be explained by the fact that $\mathrm{N}$ is the main limiting nutrient in these environments [28], although high intensity fires can convert soil organic nitrogen to inorganic forms [43]. Furthermore, phosphorus increases its availability under high severity situations [85], but losses through volatilization or leaching are smaller than nitrogen. This is especially relevant in areas of the southeastern Iberian Peninsula characterized by soils rich in phosphorus [86]. This new situation can induce plants to increase their demand for nitrogen to maintain their stoichiometry. Therefore, the input of $\mathrm{N}$ into the system and increase in its availability may be enhanced by the recovery of species with $\mathrm{N}_{2}$-fixing capacity [44] to the detriment of no $\mathrm{N}_{2}$-fixing species in $\mathrm{N}$-limited areas.

With regards to plant regenerative traits, vegetation regeneration increased with burn severity two years after the Cabrera wildfire, regardless of plant reproductive strategy. In Gátova, the recovery of obligate seeder species decreased with burn severity, but the cover of facultatives significantly increased under moderate and high severity situations. Post-fire recovery is closely related to reproductive traits since they may influence strategies used by plants to face drought conditions [87], vegetation response to post-fire rainfall patterns [71], and the mechanisms of plants to obtain resources [88].

In this context, resprouter species regenerated rapidly under the effects of high severity in the more humid area, compared to the hotter and drier site, almost reaching unburned cover values. In fact, this reproductive strategy is considered a fitness advantage in areas with high recurrence of fires [89], such as the Cabrera mountain range [90], and a trait that enables vegetation to face high severity wildfires [28]. Resprouters usually have a more developed root system that allows better access to water reserves [87], which could make them more resistant to drought seasons [70]. Moreover, the ability to regenerate vegetatively from bud banks is also related to good post-fire regeneration of resprouter vegetation [61]. In the Cabrera study site, post-fire cover of species with resprouting ability increased with burn severity regardless of bud type. However, this increment was 
more defined by belowground bud species. In this sense, it is common that individuals with belowground buds resprout easily after high severity conditions, since their storage organs are less exposed $[65,67]$. However, although fire may destroy the cambium in stems, some strategies, such as a thicker bark, may still allow vegetation to resprout from aerial buds $[62,67,91]$, which could explain the regeneration of resprouter and facultative species with aboveground buds.

The cover of obligate seeders dominated in Gátova, but these species were barely present in the Cabrera study area. In fact, germination is a very common regeneration strategy in Mediterranean regions with drier and hotter climates $[28,88]$. However, obligate seeders were negatively affected by burn severity in this site, which presented low cover values even under low severity conditions. This showed poor regeneration of the dominant species, $P$. halepensis, an obligate seeder with no heat-stimulated germination. The seeds of this species may not be as resistant to high temperatures as those of other pine species [92], so temperatures reached at high severity situations may produce high seed mortality and therefore low seedling density after fire [14]. Moreover, the processes of competition between germinated seedlings may also influence the regeneration of this species over the short term $[13,93]$. In addition, shorter rainfall periods may affect post-fire emergence, survival, and growth of obligate seeders more adversely than resprouters [70,71], since suitable soil conditions and water availability are required for seedling recruitment [94]. Despite the low presence of obligate seeders in the Cabrera study area, species regeneration was good under high severity conditions. In fact, some authors have highlighted germination as a reproductive strategy that promotes plant regeneration in fire-prone areas $[59,60]$. Fire may enhance seedling recruitment because dormant seeds can be stimulated by high temperatures [55]. This process occurs when the seed coat is scarified by heat [95], favoring water imbibition and promoting the germination of the soil seed bank [59]. However, temperatures at low/moderate burn severities may not be high enough to stimulate germination [58].

In the present study, the regeneration of species with heat-stimulated germination increased from low to high burn severity situations. In fact, this process is very common in many Mediterranean Cistaceae and Fabaceae species [95,96], such as some obligate seeders and facultatives present in the study areas. Therefore, heat-stimulated germination could also explain part of the regeneration observed in facultative species from both study sites. In this context, González-De Vega et al. [13] found as well a higher regeneration of facultative species under moderate severity one, three, and five years after fire. In South Africa, Marais et al. [97] documented elevated seedling recruitment of facultative Mediterranean shrubs two years post-fire. Thus, the presence of both reproductive strategies could have had a positive effect on the regeneration of these species [98].

Our results showed that burn severity influenced post-fire regeneration over the short term, mainly increasing cover values in more humid environments and negatively influencing the recovery of dominant vegetation in hotter drier areas. Identification of the functional plant traits that explain greater vegetation recovery according to different severity situations is of special interest, especially in fire-prone areas. In general, vegetation with $\mathrm{N}_{2}$-fixing capacity, resprouting ability, and heat-stimulated germination responded better to burn severity. In this context, the ability of many early successional species to increase available $\mathrm{N}$ [99], the allocation of resources in storage organs and a better accessibility to water of resprouters [100], and the tolerance of some seeds to high temperatures and recurrent fires [59] may enhance vegetation regeneration.

This approach shows evidence of the effects of burn severity in the most vulnerable vegetation in relation to the environment. In this sense, climate conditions characterized by higher average temperatures and lower annual rainfall may have played an important role in vegetation recovery. The study of vegetation regeneration through plant functional traits could be an interesting approach to understanding current fire regimes [3], and to face future predictions on fire behavior in Mediterranean ecosystems under a climate change context [5], as it may provide us with information about the response of areas frequently 
affected by severe fires. This could therefore be a key element in fire management in Mediterranean Basin forests in the framework of global change [101]. In such a way, the most resistant and resilient vegetation could be taken into consideration in these type of management strategies $[27,102]$. Therefore, studying the long-term response of vegetation in relation to plant functional traits may also offer an interesting approach about how vegetation is able to face current fire regimes and cope with global change and, therefore, about those species and environments that require a priority management [103].

\section{Conclusions}

The present study provides evidence of the effects of burn severity on vegetation regeneration as a function of plant physiological and regenerative traits in two different Mediterranean areas in Spain, one being characterized by mild temperatures and frequent precipitation (Cabrera), and the other by a drier and warmer climate (Gátova).

In Cabrera, high SLA species, resprouters, and obligate seeders with heat-stimulated germination respond better to burn severity. In general, post-fire cover tends to increase under high severity compared to low and moderate severities. In Gátova, $\mathrm{N}_{2}$-fixer species, facultatives, and heat-stimulated species present better regeneration at high burn severity. However, the recovery of the predominant species is poor, both one and two years after fire, since cover decreases with burn severity. Therefore, vegetation response in Gátova changed among plant functional traits.

In general terms, vegetation covers increased over time in both study sites. However, this increment is more pronounced in the more humid area, mainly under the effect of high severity. Thus, more favorable climatic conditions could have promoted the regeneration of vegetation in the Cabrera compared to the Gátova study area.

Therefore, the results of this research further our knowledge about the response of different ecosystems to current fire regimes, which could be relevant for pre- and postfire management.

Supplementary Materials: The following are available online at https:/ /www.mdpi.com/1999-4 907/12/2/149/s1, Table S1: Classification of woody species sampled in the Cabrera study area according to the functional traits. Bud bank location (aboveground or belowground) applied for resprouter and facultative species. Heat-stimulated germination (yes or no) applied for obligate seeder and facultative species, Table S2: Classification of woody species sampled in the Gátova study area according to functional traits. Bud bank location (aboveground or belowground) applied for resprouter and facultative species. Heat-stimulated germination (yes or no) applied for obligate seeder and facultative species, Table S3: Results of the generalized linear mixed models (GLMMs) showing the effects of the burn severity variable (unburned, low, moderate, and high), effects of the time (one and two years after fire), and interaction (severity $\times$ time) on each vegetation trait in the Cabrera study area. df are degrees of freedom. Significant $p$ values are in bold face. NS (no significant), Table S4: Results of the generalized linear mixed models (GLMMs) showing the effects of the burn severity variable (unburned, low, moderate, and high), the effects of time (one and two years after fire), and interaction (severity $\times$ time), on each vegetation trait in the Gátova study area. $\mathrm{df}$ are degrees of freedom. Significant $\mathrm{p}$ values are in bold face. NS (no significant).

Author Contributions: S.H., E.M., S.S.-S., and L.C. conceived and designed the experiment; S.H., V.F.-G., E.M., S.S.-S., and L.C. obtained vegetation data in the field; S.H. and V.F.-G. analyzed the data; S.H. wrote the manuscript; V.F.-G., E.M., S.S.-S.; and L.C. revised the manuscript; E.M. and L.C. coordinated the study. All authors have read and agreed to the published version of the manuscript.

Funding: This study was financially supported by the Spanish Ministry of Economy and Competitiveness in the framework of the FIRESEVES (AGL2017-86075-C2-1-R) project, and by the Regional Government of Castilla and León in the framework of the WUIFIRECYL (LE005P120) project. The European Regional Development Fund also provided funding for the present study. S.H. was supported by a predoctoral fellowship from the Regional Government of Castilla and León and the European Social Fund (EDU/574/2018).

Data Availability Statement: Data sharing is not applicable to this article. 
Conflicts of Interest: The authors declare no conflict of interest.

\section{References}

1. Vilén, T.; Fernandes, P.M. Forest fires in Mediterranean countries: $\mathrm{CO}_{2}$ emissions and mitigation possibilities through prescribed burning. Environ. Manag. 2011, 48, 558-567. [CrossRef] [PubMed]

2. Pausas, J.G. Changes in fire and climate in the eastern Iberian Peninsula (Mediterranean Basin). Clim. Chang. 2004, 63, 337-350. [CrossRef]

3. Moreno, M.V.; Conedera, M.; Chuvieco, E.; Pezzatti, G.B. Fire regime changes and major driving forces in Spain from 1968 to 2010. Environ. Sci. Policy 2014, 37, 11-22. [CrossRef]

4. Pausas, J.G.; Vallejo, V.R. The role of fire in European Mediterranean ecosystems. In Remote Sensing of Large Wildfires in the European Mediterranean Basin; Chuvieco, E., Ed.; Springer: Berlin/Heidelberg, Germany, 1999; pp. 3-16; ISBN 978-3-642-60164-4.

5. Moreira, F.; Viedma, O.; Arianoutsou, M.; Curt, T.; Koutsias, N.; Rigolot, E.; Barbati, A.; Corona, P.; Vaz, P.; Xanthopoulos, G.; et al. Landscape-wildfire interactions in southern Europe: Implications for landscape management. J. Environ. Manag. 2011, 92, $2389-2402$. [CrossRef]

6. Hinojosa, M.B.; Parra, A.; Laudicina, V.A.; Moreno, J.M. Post-fire soil functionality and microbial community structure in a Mediterranean shrubland subjected to experimental drought. Sci. Total Environ. 2016, 573, 1178-1189. [CrossRef]

7. Pereira, P.; Rein, G.; Martin, D. Past and present post-fire environments. Sci. Total Environ. 2016, 573, 1275-1277. [CrossRef]

8. Pausas, J.G.; Llovet, J.; Rodrigo, A.; Vallejo, R. Are wildfires a disaster in the Mediterranean Basin? A review. Int. J. Wildland Fire 2008, 17, 713-723. [CrossRef]

9. Pausas, J.G.; Bradstock, R.A.; Keith, D.A.; Keeley, J.E. Plant functional traits in relation to fire in crown-fire ecosystems. Ecology 2004, 85, 1085-1100. [CrossRef]

10. Pausas, J.G.; Verdú, M. Plant persistence traits in fire-prone ecosystems of the Mediterranean Basin: A phylogenetic approach. Oikos 2005, 109, 196-202. [CrossRef]

11. Vallejo, V.R.; Arianoutsou, M.; Moreira, F. Fire ecology and post-fire restoration approaches in southern European forest types. In Post-Fire Management and Restoration of Southern European Forests; Moreira, F., Arianoutsou, M., Corona, P., De Las Heras, J., Eds.; Springer: Dordrecht, The Netherlands, 2012; pp. 93-119. ISBN 978-94-007-2208-8.

12. Crotteau, J.S.; Morgan Varner, J.; Ritchie, M.W. Post-fire regeneration across a fire severity gradient in the southern Cascades. For. Ecol. Manag. 2013, 287, 103-112. [CrossRef]

13. González-De Vega, S.; De las Heras, J.; Moya, D. Post-fire regeneration and diversity response to burn severity in Pinus halepensis Mill. forests. Forests 2018, 9, 299. [CrossRef]

14. Fernández-García, V.; Fulé, P.Z.; Marcos, E.; Calvo, L. The role of fire frequency and severity on the regeneration of Mediterranean serotinous pines under different environmental conditions. For. Ecol. Manag. 2019, 444, 59-68. [CrossRef]

15. Pausas, J.G.; Bradstock, R.A. Fire persistence traits of plants along a productivity and disturbance gradient inmediterranean shrublands of south-east Australia. Glob. Ecol. Biogeogr. 2007, 16, 330-340. [CrossRef]

16. Calvo, L.; Tárrega, R.; Luis, E. Regeneration in Quercus pyrenaica ecosystems after surface fires. Int. J. Wildland Fire 1991, 1, 205-210. [CrossRef]

17. Calvo, L.; Tárrega, R.; de Luis, E. Post-fire succession in two Quercus pyrenaica communities with different disturbance histories. Ann. For. Sci. 1999, 56, 441-447. [CrossRef]

18. Calvo, L.; Tárrega, R.; de Luis, E. Secondary succession after perturbations in a shrubland community. Acta Oecol. 2002, 23, 393-404. [CrossRef]

19. Calvo, L.; Santalla, S.; Marcos, E.; Valbuena, L.; Tárrega, R.; Luis, E. Regeneration after wildfire in communities dominated by Pinus pinaster, an obligate seeder, and in others dominated by Quercus pyrenaica, a typical resprouter. For. Ecol. Manag. 2003, 184, 209-223. [CrossRef]

20. Calvo, L.; Santalla, S.; Valbuena, L.; Marcos, E.; Tárrega, R.; Luis-Calabuig, E. Post-fire natural regeneration of a Pinus pinaster forest in NW Spain. Plant. Ecol. 2008, 197, 81-90. [CrossRef]

21. González-De Vega, S.; De las Heras, J.; Moya, D. Resilience of Mediterranean terrestrial ecosystems and fire severity in semiarid areas: Responses of Aleppo pine forests in the short, mid and long term. Sci. Total Environ. 2016, 573, 1171-1177. [CrossRef]

22. Violle, C.; Navas, M.-L.; Vile, D.; Kazakou, E.; Fortunel, C.; Hummel, I.; Garnier, E. Let the concept of trait be functional! Oikos 2007, 116, 882-892. [CrossRef]

23. Buhk, C.; Meyn, A.; Jentsch, A. The challenge of plant regeneration after fire in the Mediterranean Basin: Scientific gaps in our knowledge on plant strategies and evolution of traits. Plant. Ecol. 2007, 192, 1-19. [CrossRef]

24. Bradshaw, S.D.; Dixon, K.W.; Hopper, S.D.; Lambers, H.; Turner, S.R. Little evidence for fire-adapted plant traits in Mediterranean climate regions. Trends Plant. Sci. 2011, 16, 69-76. [CrossRef] [PubMed]

25. Pausas, J.G. Response of plant functional types to changes in the fire regime in Mediterranean ecosystems: A simulation approach. J. Veg. Sci. 1999, 10, 717-722. [CrossRef]

26. Calvo, L.; Baeza, J.; Marcos, E.; Santana, V.; Papanastasis, V.P. Post-Fire management of shrublands. In Post-Fire Management and Restoration of Southern European Forests. Maraging Forest Ecosystems; Moreira, F., Arianoutsou, M., Corona, P., De las Heras, J., Eds.; Springer: Dordrecht, The Netherlands, 2012; pp. 293-319; ISBN 978-94-007-2208-8. 
27. Enright, N.J.; Fontaine, J.B.; Lamont, B.B.; Miller, B.P.; Westcott, V.C. Resistance and resilience to changing climate and fire regime depend on plant functional traits. J. Ecol. 2014, 102, 1572-1581. [CrossRef]

28. Fernández-García, V.; Marcos, E.; Fulé, P.Z.; Reyes, O.; Santana, V.M.; Calvo, L. Fire regimes shape diversity and traits of vegetation under different climatic conditions. Sci. Total Environ. 2020, 716, 137137. [CrossRef] [PubMed]

29. Anacker, B.; Rajakaruna, N.; Ackerly, D.; Harrison, S.; Keeley, J.; Vasey, M. Ecological strategies in California chaparral: Interacting effects of soils, climate, and fire on specific leaf area. Plant. Ecol. Divers. 2011, 4, 179-188. [CrossRef]

30. Souza, M.C.; Rossatto, D.R.; Cook, G.D.; Fujinuma, R.; Menzies, N.W.; Morellato, L.P.C.; Habermann, G. Mineral nutrition and specific leaf area of plants under contrasting long-term fire frequencies: A case study in a mesic savanna in Australia. Trees 2016, 30, 329-335. [CrossRef]

31. Casals, P.; Valor, T.; Rios, A.I.; Shipley, B. Leaf and bark functional traits predict resprouting strategies of understory woody species after prescribed fires. For. Ecol. Manag. 2018, 429, 158-174. [CrossRef]

32. Wright, I.J.; Cooke, J.; Cernusak, L.A.; Hutley, L.B.; Scalon, M.C.; Tozer, W.C.; Lehmann, C.E.R. Stem diameter growth rates in a fire-prone savanna correlate with photosynthetic rate and branch-scale biomass allocation, but not specific leaf area. Austral. Ecol. 2019, 44, 339-350. [CrossRef]

33. Wright, I.J.; Reich, P.B.; Cornelissen, J.H.C.; Falster, D.S.; Groom, P.K.; Hikosaka, K.; Lee, W.; Lusk, C.H.; Niinemets, U.; Oleksyn, J.; et al. Modulation of leaf economic traits and trait relationships by climate. Glob. Ecol. Biogeogr. 2005, 14, 411-421. [CrossRef]

34. Wright, I.J.; Westoby, M. Cross-species relationships between seedling relative growth rate, nitrogen productivity and root vs leaf function in 28 Australian woody species. Funct. Ecol. 2000, 14, 97-107. [CrossRef]

35. Reich, P.B.; Walters, M.B.; Ellsworth, D.S.; Vose, J.M.; Volin, J.C.; Gresham, C.; Bowman, W.D. Relationships of leaf dark respiration to leaf nitrogen, specific leaf area and leaf life-span: A test across biomes and functional groups. Oecologia 1998, 114, 471-482. [CrossRef] [PubMed]

36. Dwyer, J.M.; Hobbs, R.J.; Mayfield, M.M. Specific leaf area responses to environmental gradients through space and time. Ecology 2014, 95, 399-410. [CrossRef] [PubMed]

37. Caon, L.; Vallejo, V.R.; Ritsema, C.J.; Geissen, V. Effects of wildfire on soil nutrients in Mediterranean ecosystems. Earth Sci. Rev. 2014, 139, 47-58. [CrossRef]

38. Fernández-García, V.; Marcos, E.; Reyes, O.; Calvo, L. Do fire regime attributes affect soil biochemical properties in the same way under different environmental conditions? Forests 2020, 11, 274. [CrossRef]

39. LeBauer, D.S.; Treseder, K.K. Nitrogen limitation of net primary productivity in terrestrial ecosystems is globally distributed. Ecology 2008, 89, 371-379. [CrossRef]

40. Marcos, E.; Villalón, C.; Calvo, L.; Luis-Calabuig, E. Short-term effects of experimental burning on soil nutrients in the Cantabrian heathlands. Ecol. Eng. 2009, 35, 820-828. [CrossRef]

41. Franche, C.; Lindström, K.; Elmerich, C. Nitrogen-fixing bacteria associated with leguminous and non-leguminous plants. Plant. Soil 2009, 321, 35-59. [CrossRef]

42. Bernhard, A. The nitrogen cycle: Processes, players, and human impact. Nat. Educ. Knowl. 2010, $2,12$.

43. Certini, G. Effects of fire on properties of forest soils: A review. Oecologia 2005, 143, 1-10. [CrossRef]

44. Vourlitis, G.L.; Pasquini, S.C. Carbon and nitrogen dynamics of pre- and post-fire chaparral exposed to varying atmospheric N deposition. J. Arid Environ. 2008, 72, 1448-1463. [CrossRef]

45. Newland, J.A.; DeLuca, T.H. Influence of fire on native nitrogen-fixing plants and soil nitrogen status in ponderosa pineDouglas-fir forests in western Montana. Can. J. For. Res. 2000, 30, 274-282. [CrossRef]

46. Valbuena, L.; Tárrega, R.; Luis, E. Influence of heat on seed germination of Cistus laurifolius and Cistus ladanifer. Int. J. Widland Fire 1992, 2, 15-20. [CrossRef]

47. Calvo, L.; Tárrega, R.; de Luis, E. Space-time distribution patterns of Erica australis L. subsp. aragonensis (Willk) after experimental burning, cutting, and ploughing. Plant. Ecol. 1998, 137, 1-12. [CrossRef]

48. Calvo, L.; Tárrega, R.; De Luis, E. The dynamics of Mediterranean shrubs species over 12 years following perturbations. Plant. Ecol. 2002, 160, 25-42. [CrossRef]

49. Pausas, J.G.; Keeley, J.E. Evolutionary ecology of resprouting and seeding in fire-prone ecosystems. New Phytol. 2014, 204, 55-65. [CrossRef]

50. Lloret, F. Fire, canopy cover and seedling dynamics in Mediterranean shrubland of northeastern Spain. J. Veg. Sci. 1998, 9, 417-430. [CrossRef]

51. Verdú, M. Ecological and evolutionary differences between Mediterranean seeders and resprouters. J. Veg. Sci. 2000, 11, 265-268. [CrossRef]

52. Arnan, X.; Rodrigo, A.; Retana, J. Post-fire regeneration of Mediterranean plant communities at a regional scale is dependent on vegetation type and dryness. J. Veg. Sci. 2007, 18, 111-122. [CrossRef]

53. De Luis, M.; Raventós, J.; González-Hidalgo, J.C. Post-fire vegetation succession in Mediterranean gorse shrublands. Acta Oecol. 2006, 30, 54-61. [CrossRef]

54. Núñez, M.R.; Calvo, L. Effect of high temperatures on seed germination of Pinus sylvestris and Pinus halepensis. For. Ecol. Manag. 2000, 131, 183-190. [CrossRef]

55. Keeley, J.E. Role of fire in seed germination of woody taxa in California chaparral. Ecology 1987, 68, 434-443. [CrossRef] 
56. Torres, O.; Calvo, L.; Valbuena, L. Influence of high temperatures on seed germination of a special Pinus pinaster stand adapted to frequent fires. Plant. Ecol. 2006, 186, 129-136. [CrossRef]

57. Álvarez, R.; Valbuena, L.; Calvo, L. Effect of high temperatures on seed germination and seedling survival in three pine species (Pinus pinaster, P. sylvestris and P. nigra). Int. J. Wildland Fire 2007, 16, 63-70. [CrossRef]

58. Wright, B.R.; Latz, P.K.; Zuur, A.F. Fire severity mediates seedling recruitment patterns in slender mulga (Acacia aptaneura), a fire-sensitive Australian desert shrub with heat-stimulated germination. Plant. Ecol. 2016, 217, 789-800. [CrossRef]

59. Lamont, B.B.; He, T.; Yan, Z. Evolutionary history of fire-stimulated resprouting, flowering, seed release and germination. Biol. Rev. 2019, 94, 903-928. [CrossRef]

60. Moreira, B.; Pausas, J.G. Tanned or burned: The role of fire in shaping physical seed dormancy. PLoS ONE 2012, 7, e51523. [CrossRef]

61. Klimesová, J.; Klimes, L. Bud banks and their role in vegetative regeneration-A literature review and proposal for simple classification and assessment. Perspect. Plant. Ecol. 2007, 8, 115-129. [CrossRef]

62. Clarke, P.J.; Lawes, M.J.; Midgley, J.J.; Lamont, B.B.; Ojeda, F.; Burrows, G.E.; Enright, N.J.; Knox, K.J.E. Resprouting as a key functional trait: How buds, protection and resources drive persistence after fire. New Phytol. 2013, 197, 19-35. [CrossRef]

63. Moreira, B.; Tormo, J.; Pausas, J.G. To resprout or not to resprout: Factors driving intraspecific variability in resprouting. Oikos 2012, 121, 1577-1584. [CrossRef]

64. Reyes, O.; Casal, M.; Rego, F.C. Resprouting ability of six atlantic shrub species. Folia Geobot. 2009, 44, 19-29. [CrossRef]

65. Bellingham, P.J.; Sparrow, A.D. Resprouting as a life history strategy in woody plant communities. Oikos 2000, 89, 409-416. [CrossRef]

66. Keeley, J.E. Fire severity and plant age in postfire resprouting of woody plants in sage scrub and chaparral. Madroño 2006, 53, 373-379. [CrossRef]

67. Wright, B.R.; Clarke, P.J. Resprouting responses of Acacia shrubs in theWestern Desert of Australia-Fire severity, interval and season influence survival. Int. J. Wildland Fire 2007, 16, 317-323. [CrossRef]

68. Pausas, J.G.; Carbó, E.; Caturla, R.N.; Gil, J.M.; Vallejo, R. Post-fire regeneration patterns in the eastern Iberian Peninsula. Acta Oecol. 1999, 20, 499-508. [CrossRef]

69. Lloret, F.; Peñuelas, J.; Prieto, P.; Llorens, L.; Estiarte, M. Plant community changes induced by experimental climate change: Seedling and adult species composition. Perspect. Plant. Ecol. Evol. Syst. 2009, 11, 53-63. [CrossRef]

70. Parra, A.; Moreno, J.M. Post-fire environments are favourable for plant functioning of seeder and resprouter Mediterranean shrubs, even under drought. New Phytol. 2017, 214, 1118-1131. [CrossRef]

71. Parra, A.; Moreno, J.M. Drought differentially affects the post-fire dynamics of seeders and resprouters in a Mediterranean shrubland. Sci. Total Environ. 2018, 626, 1219-1229. [CrossRef]

72. Air Temperature and Precipitation (1971-2000). Iberian Climate Atlas; Agencia Estatal de Meteorología, Ministerio de Medio Ambiente y Medio Rural y Marino; Instituto de Meteorologia de Portugal: Lisbon, Portugal, 2011; pp. 1-80. ISBN 978-84-7837-079-5.

73. Ninyerola, M.; Pons, X.; Roure, J.M. Atlas Climático Digital de la Península Ibérica. Metodología y Aplicaciones en Bioclimatología y Geobotánica; Universidad Autónoma de Barcelona: Bellaterra, Spain, 2005; pp. 1-44. ISBN 932860-8-7.

74. IGME (Instituto Geológico y Minero de España). GEODE. Mapa Geológico Digital continuo de España. Available online: http:/ / mapas.igme.es/gis/rest/services/Cartografia_Geologica/IGME_Geode_50/MapServer (accessed on 11 April 2020).

75. Fernández-García, V.; Santamarta, M.; Fernández-Manso, A.; Quintaro, C.; Marcos, E.; Calvo, L. Burn severity metrics in fire-prone pine ecosystems along a climatic gradient using Landsat imagery. Remote Sens. Environ. 2018, 206, 205-217. [CrossRef]

76. Tavsanoglu, Ç.; Pausas, J.G. A functional trait database for Mediterranean Basin plants. Sci. Data 2018, 5, 180135. [CrossRef]

77. López-Soria, L.; Castell, C. Comparative genet survival after fire in woody Mediterranean species. Oecologia 1992, 91, 493-499. [CrossRef] [PubMed]

78. Maubon, M.; Ponge, J.F.; André, J. Dynamics of Vaccinium myrtillus patches in mountain spruce forest. J. Veg. Sci. 1995, 6, 343-348. [CrossRef]

79. Calvo, L.; Tárrega, R.; Luis, E. Regeneration patterns in a Calluna vulgaris heathland in the Cantabrian mountains (NW Spain): Effects of burning, cutting and ploughing. Acta Oecol. 2002, 23, 81-90. [CrossRef]

80. Meira-Neto, J.A.A.; Clemente, A.; Oliveira, G.; Nunes, A.; Correia, O. Post-fire and post-quarry rehabilitation successions in Mediterranean-like ecosystems: Implications for ecological restoration. Ecol. Eng. 2011, 37, 1132-1139. [CrossRef]

81. Pérez-Fernández, M.A.; Lamont, B.B. Competition and facilitation between Australian and Spanish legumes in seven Australian soils. Plant. Spec. Biol. 2016, 31, 256-271. [CrossRef]

82. R: A Language and Environment for Statistical Computing. R Foundation for Statistical Computing. Available online: http: //www.R-project.org/ (accessed on 11 December 2020).

83. Venables, W.N.; Ripley, B.D. Modern Applied Statistics with S, 4th ed.; Springer: New York, NY, USA, 2002.

84. Nlme: Linear and Nonlinear Mixed Effects Models. R Package Version 3.1-151. Available online: https://CRAN.R-project.org/ package $=$ nlme (accessed on 11 December 2020).

85. Fernández-García, V.; Marcos, E.; Fernández-Guisuraga, J.M.; Taboada, A.; Suárez-Seoane, S.; Calvo, L. Impact of burn severity on soil properties in a Pinus pinaster ecosystem immediately after fire. Int. J. Wildland Fire 2019, 28, 354-364. [CrossRef]

86. Fernández-García, V.; Miesel, J.; Baeza, M.J.; Marcos, E.; Calvo, L. Wildfire effects on soil properties in fire-prone pine ecosystems: Indicators of burn severity legacy over the medium term after fire. Appl. Soil Ecol. 2019, 135, 147-156. [CrossRef] 
87. Clemente, A.S.; Rego, F.C.; Correia, O.A. Growth, water relations and photosynthesis of seedlings and resprouts after fire. Acta Oecol. 2005, 27, 233-243. [CrossRef]

88. Lloret, F.; Estevan, H.; Vayreda, J.; Terradas, J. Fire regenerative syndromes of forest woody species across fire and climatic gradients. Oecologia 2005, 146, 461-468. [CrossRef]

89. Lamont, B.B.; Enright, N.J.; He, T. Fitness and evolution of resprouters in relation to fire. Plant. Ecol. 2011, $212,1945-1957$. [CrossRef]

90. García-Llamas, P.; Suárez-Seoane, S.; Fernández-Manso, A.; Quintaro, C.; Calvo, L. Evaluation of fire severity in fire proneecosystems of Spain under two different environmental conditions. J. Environ. Manag. 2020, 271, 110706. [CrossRef]

91. Vesk, P.A.; Westoby, M. Sprouting ability across diverse disturbances and vegetation types worldwide. J. Ecol. 2004, 92, 310-320. [CrossRef]

92. Martínez-Sánchez, J.J.; Marín, A.; Herranz, J.M.; Ferrandis, P.; De las Heras, J. Effects of high temperatures on germination of Pinus halepensis Mill. and P. pinaster Aiton subsp. pinaster seeds in south east Spain. Vegetatio 1995, 116, 69-72. [CrossRef]

93. Sagra, J.; Moya, D.; Plaza-Álvarez, P.A.; Lucas-Borja, M.E.; Alfaro-Sánchez, R.; De las Heras, J.; Ferrandis, P. Predation on early recruitment in Mediterranean forests after prescribed fires. Forests 2017, 8, 243. [CrossRef]

94. Saracino, A.; Pacella, R.; Leone, V.; Borghetti, M. Seed dispersal and changing seed characteristics in a Pinus halepensis Mill. forest after fire. Plant. Ecol. 1997, 130, 13-19. [CrossRef]

95. Tárrega, R.; Calvo, L.; Trabaud, L. Effect of high temperatures on seed germination of two woody Leguminosae. Vegetatio 1992, 102, 139-147. [CrossRef]

96. Herranz, J.M.; Ferrandis, P.; Martínez-Sánchez, J.J. Influence of heat on seed germination of seven Mediterranean Leguminosae species. Plant. Ecol. 1998, 136, 95-103. [CrossRef]

97. Marais, K.E.; Pratt, R.B.; Jacobs, S.M.; Jacobsen, A.L.; Esler, K.J. Postfire regeneration of resprouting mountain fynbos shrubs: Differentiating obligate resprouters and facultative seeders. Plant. Ecol. 2014, 215, 195-208. [CrossRef]

98. Bradbury, D.; Tapper, S.-L.; Coates, D.; Hankinson, M.; McArthur, S.; Byrne, M. How does the post-fire facultative seeding strategy impact genetic variation and phylogeographical history? The case of Bossiaea ornata (Fabaceae) in a fire-prone, mediterraneanclimate ecosystem. J. Biogeogr. 2016, 43, 96-110. [CrossRef]

99. Crews, T.E. The presence of nitrogen fixing legumes in terrestrial communities: Evolutionary vs ecological considerations. Biogeochemistry 1999, 46, 233-246. [CrossRef]

100. Pausas, J.G.; Pratt, R.B.; Keeley, J.E.; Jacobsen, A.L.; Ramirez, A.R.; Vilagrosa, A.; Paula, S.; Kaneakua-Pia, I.N.; Davis, S.D. Towards understanding resprouting at the global scale. New Phytol. 2016, 209, 945-954. [CrossRef]

101. Fernandes, P.M. Fire-smart management of forest landscapes in the Mediterranean basin under global change. Landsc. Urban. Plan. 2013, 110, 175-183. [CrossRef]

102. Stephens, S.L.; Millar, C.I.; Collins, B.M. Operational approaches to managing forests of the future in Mediterranean regions within a context of changing climates. Environ. Res. Lett. 2010, 5, 024003. [CrossRef]

103. Keith, D.A.; Holman, L.; Rodoreda, S.; Lemmon, J.; Bedward, M. Plant functional types can predict decade-scale changes in fire-prone vegetation. J. Ecol. 2007, 95, 1324-1337. [CrossRef] 